\title{
An Efficient and Green Route to Synthesize Azo Compounds through Methyl Nitrite
}

\author{
Kejie Cai, Hongqiang He, Yuwei Chang, Weiming Xu \\ College of Material Chemistry and Chemical Engineering, Hangzhou Normal University, Hangzhou, China \\ Email: wmxu@hznu.edu.cn
}

Received 4 May 2014; revised 3 June 2014; accepted 3 July 2014

Copyright (C) 2014 by authors and Scientific Research Publishing Inc.

This work is licensed under the Creative Commons Attribution International License (CC BY).

http://creativecommons.org/licenses/by/4.0/

(c) (i) Open Access

\begin{abstract}
A clean preparation of aryl diazonium ions using methyl nitrite is described. Further reaction of the aryl diazonium ions with substituted benzenamine, substituted phenol and nathphol in deferent kinds of diazotization has been developed. In order to improve the water-solubility of the products, azo coupling reactions of sodium sulfanilate hydrochloride diazonium ions were also performed. The procedures are easy operations, environmentally benign conditions and high yields of the products with potential use as azo-dyes and pigments. Furthermore, no nitrous acid is produced during the diazotization which avoided the formation of dark decomposition products of the corresponding aromatic amine. Proposed mechanism is presented according to our procedure.
\end{abstract}

\section{Keywords}

Methyl Nitrite, Substituted Benzenamine, Diazotization, Azo Coupling, Dyes, Pigments, Environmentally Benign, Toxicological

\section{Introduction}

Aryl diazonium salts have been discovered in the middle of the 19th century by Johann Peter Griess who was working on azo-compounds as dyes and pigments [1]. Commonly, they are prepared by diazotization [2], a procedure in which a primary aromatic amine is treated with a source of nitrous acid $\left(\mathrm{HNO}_{2}\right)$. In spite of all precautions the formation of dark decomposition products due to the existence of nitrous acid and its aromatic amine is unavoidable, thus lowering the yield and also making the product difficult to isolate [3].

Environmental and toxicological concerns have resulted in increased interests in new diazotization reaction. Among them, the Sandmeyer Reaction is widely studied using either polymer supported acid [4] or polymer supported nitrite [5] to stabilize the aryl diazonium ions, which makes it easy to separate from the reaction mix-

How to cite this paper: Cai, K.J., He, H.Q., Chang, Y.W. and Xu, W.M. (2014) An Efficient and Green Route to Synthesize Azo Compounds through Methyl Nitrite. Green and Sustainable Chemistry, 4, 111-119. 
ture. In addition, azo coupling reaction on clays was also carried out to prepare the azo-dyes [6]. But most of these reactions were carried out in a heterogeneous medium. As a potentially attractive alternative to the traditional methods, isoamyl nitrite, instead of nitrous acid, has also been reported to perform the diazotization. As the reaction undergoes a radical machenism, a lot of organic solvents are used in many cases [7].

Based on our study of diazotizing reaction through methyl nitrite to prepare versatile intermediate 5,5'-methylene-bis(benzotriazole) [8], we have developed here a practical and clean diazotizing reagent and its further widely use in deferent kinds of diazotization. The procedures are very simple as methyl nitrite is a low boiling point gas (bp. $-12^{\circ} \mathrm{C}$; mp. $-17^{\circ} \mathrm{C}$ ), which could be easily purified and bubbled through the reaction mixture and recovered through a cold-trap after the reaction. Furthermore, no nitrous acid is used during the diazotization which led to the procedure with easy operations, environmentally benign conditions and high yields of the products.

\section{Results and Discussion}

We began our efforts from methyl nitrite, which was easily prepared from sodium nitrite, methanol and hydrochloric acid, bubbled through a solution of 4-methylaniline via the gas tube, without further purification, 1,3-dimethyl-1,2,3-triazene was obtained with $96 \%$ of yield (Scheme 1). For the diazonium solution could not be stably existed in the solution of 4-methylaniline.

Upon further investigation, we found that the obtained aryl diazonium ions could be stably existed when aromatic amine hydrochloride, instead of aromatic amine, was used as substrate. Because the color center of the dye or pigment was the azo $(\mathrm{N}=\mathrm{N})$ group, azo coupling reactions of $\mathrm{N}, \mathrm{N}$-dimethyl benzenamine and 3,5-dimethylaniline, substituted phenol, nathphol with substituted aryl hydrochloride diazonium ions were performed in order to expand the diversity of the azo $(\mathrm{N}=\mathrm{N})$ group (Scheme 2). Results are described in Table 1.

The nature of the aromatic substituents on both sides of the azo group controls the colours of the azo compounds as well as the water-solubility of the dyes. In order to improve the water-solubility of the dyes, the sodium sulfanilate is common used in most case. In our procedure, azo coupling reactions of sodium sulfanilate hydrochloride diazonium ions with N,N-dimethyl benzenamine, substituted phenol and nathphol (Scheme 3) were also performed. Results are described in Table 2.

It was noteworthy that in our procedure no nitrous acid was used and proposed mechanism of the diazotization reaction was presented (Figure 1).

\section{Experimental}

Starting materials were obtained from commercial suppliers and used without further purification. ${ }^{1} \mathrm{H}$ NMR (400 $\mathrm{MHz}$ or $500 \mathrm{MHz}$ ) and ${ }^{13} \mathrm{C}$ NMR (100 MHz) spectra were recorded on a Bruker Avance (400 MHz) spectrometer, using $\mathrm{CDCl}_{3}$ or $\mathrm{C}_{6} \mathrm{D}_{6}$ or $d$-DMSO as the solvent and TMS as internal standard. Infrared spectra were recorded on a Bruker V-22 spectrometer. Elemental analyses were performed on a Flash EA1112 instrument.

Preparation of methyl nitrite: In a $500 \mathrm{~mL}$ round-bottomed flask, fitted with a pressure equalizing addition funnel filled with $110 \mathrm{~mL} 12 \mathrm{M}$ hydrochloric acid, and a gas tube in a well ventilated hood, was placed $76.0 \mathrm{~g}$ $(1.1 \mathrm{~mol})$ of sodium nitrite, $60 \mathrm{~mL}$ methanol and $110 \mathrm{~mL}$ water. The temperature was raised to $35^{\circ} \mathrm{C}$ and hydrochloric acid was added dropwise over $1.5 \mathrm{~h}$. The methyl nitrite evolved was passed through a water trap and a $10 \%$ sodium carbonate trap to remove acid and then bubbled through the reaction mixture below via the gas tube.

Preparation of the 4-methylaniline hydrochloride diazonium solution; (used in Scheme 1): In a $1 \mathrm{~L}$ round-bottomed flask, fitted with a mechanical stirrer, and a gas tube in a well-ventilated hood, was placed $143.7 \mathrm{~g}$ (1.0 mol) of 4-methylaniline hydrochloride and $300 \mathrm{~mL}$ methanol. Methyl nitrite $(1.1 \mathrm{~mol})$ was added through the tube for about $1.5 \mathrm{~h}$. When the reaction was complete, the temperature was raised to $50^{\circ} \mathrm{C}$ and the mixture was stirred for another 20 min. to expel excess methyl nitrite, which was recovered through a cold-trap.

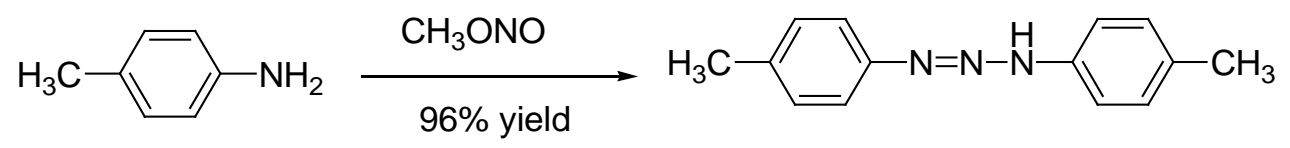

Scheme 1. Preparation of 1,3-dimethyl-1,2,3-triazene. 


$$
\begin{aligned}
& 0 \\
& 0 \\
& 0
\end{aligned}
$$


<smiles>CN(OC(=O)ON(C)c1ccccc1)Oc1ccc(N=Nc2ccc(N(C)C)cc2)cc1</smiles>

2a

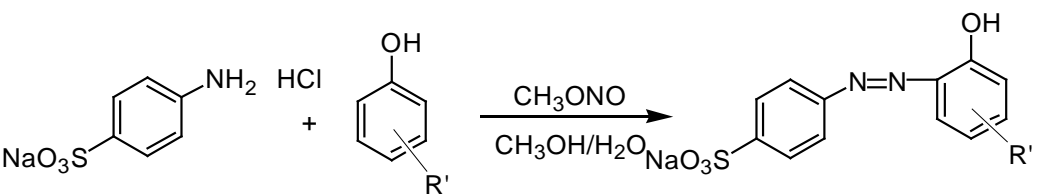

2b, 2c, 2d

Scheme 3. Preparation of azo coupling reactions of sodium sulfanilate hydrochloride diazonium ions.

Table 1. Synthesis of azo compounds.

\begin{tabular}{cccc}
\hline Product $^{\mathrm{a}}$ & Substrate & Substrate & ${\text { Yield }(\%)^{\mathrm{b}}}^{\mathrm{b}}$ \\
$\mathbf{1 a}$ & 4-methylaniline & 3,5-dimethylaniline & 86 \\
$\mathbf{1 b}$ & 4-methylaniline & N,N-dimethylaniline & 94 \\
$\mathbf{1 c}$ & 4-methylaniline & 4-methylphenol & 81 \\
$\mathbf{1 d}$ & 4-methylaniline & 4-hydroxyacetophenone & 96 \\
$\mathbf{1 e}$ & 4-methylaniline & 2-naphthol & 93 \\
$\mathbf{1 f}$ & aniline & 4-methylphenol & 91 \\
$\mathbf{1 g}$ & aniline & 2-naphthol & 85 \\
$\mathbf{1 h}$ & 4-nitroaniline & phenol & 83 \\
$\mathbf{1 i}$ & 4-nitroaniline & 6-ethyl-2-methylaniline & 85 \\
$\mathbf{1 j}$ & 4-nitroaniline & 2-naphthol & 90 \\
$\mathbf{1 k}$ & 4-Aminoazobenzene & phenol & \\
\hline
\end{tabular}

${ }^{\mathrm{a}}$ All the products were characterized by IR, ${ }^{1} \mathrm{H}$ NMR, ${ }^{13} \mathrm{C}$ NMR and MS spectroscopy. ${ }^{\mathrm{b}}$ Isolated yield.

Table 2. Synthesis of azo compounds with sulfanilate.

\begin{tabular}{ccc}
\hline Product $^{\mathrm{a}}$ & Substrate & Yield (\%) $^{\mathrm{b}}$ \\
\hline 2a & N,N-dimethylaniline & 83 \\
2b & 1,3-dilphenol & 82 \\
2c & 2-naphthol & 88 \\
2d & 4-methylphenol & 87 \\
2e & 3,5-dimethylaniline & 81 \\
\hline
\end{tabular}

${ }^{\mathrm{a}}$ All the products were characterized by IR, ${ }^{1} \mathrm{H}$ NMR, ${ }^{13} \mathrm{C}$ NMR and MS spectroscopy. ${ }^{\mathrm{b}}$ Isolated yield.

Preparation of 3,5-dimethyl-4-(p-tolyldiazenyl)aniline (1a): To a solution of $121.1 \mathrm{~g}$ (1.0 mol) 3,5-dimethylaniline in $300 \mathrm{~mL}$ methanol, the above 4-methylaniline hydrochloride diazonium solution was added dropwise for $4 \mathrm{~h}$ at $0^{\circ} \mathrm{C}$. Then the precipitated crystals were collected, recrystallized from $60 \mathrm{~mL}$ of ethanol and dried in vacuo to afford $205.5 \mathrm{~g}(86 \%)$ of the product as a red solid; mp. $90^{\circ} \mathrm{C}-92^{\circ} \mathrm{C}$.

1a: IR $v_{\max }\left(\mathrm{cm}^{-1}\right)$ : 822, 852, 1029, 1165, 1328, 1426, 1597, 1619; ${ }^{1} \mathrm{H}$ NMR $\left(\mathrm{CDCl}_{3}\right): \delta 2.41(3 \mathrm{H}, \mathrm{s}), 2.45(6$ H, s), $3.29(2 \mathrm{H}, \mathrm{b}), 6.42(2 \mathrm{H}, \mathrm{s}), 7.27(2 \mathrm{H}, \mathrm{d}, J=8.0 \mathrm{~Hz}), 7.73(2 \mathrm{H}, \mathrm{d}, J=8.0 \mathrm{~Hz}) ;{ }^{13} \mathrm{C}$ NMR $\left(\mathrm{CDCl}_{3}\right): \mathrm{d} 20.3$, 21.3, 115.3, 122.0, 129.5, 135.3, 139.9, 142.8, 147.0, 151.5; MS m/z 91 (40), 120 (100), 148 (20), 239 (M+ 95); Elemental analysis. Calcd for $\mathrm{C}_{15} \mathrm{H}_{17} \mathrm{~N}_{3}$, C 75.28; H 7.16; N 17.56; Found C 75.07; H 7.27; N 17.66.

Preparation of N,N-dimethyl-4-(p-tolyldiazenyl)aniline (1b): To a solution of $121.1 \mathrm{~g}(1.0 \mathrm{~mol}) \mathrm{N}, \mathrm{N}-\mathrm{di}-$ methylaniline in $300 \mathrm{~mL}$ methanol, the above 4-methylaniline hydrochloride diazonium solution was added dropwise for $2 \mathrm{~h}$. Then the precipitated crystals were collected, recrystallized from $60 \mathrm{~mL}$ of ethanol and dried 

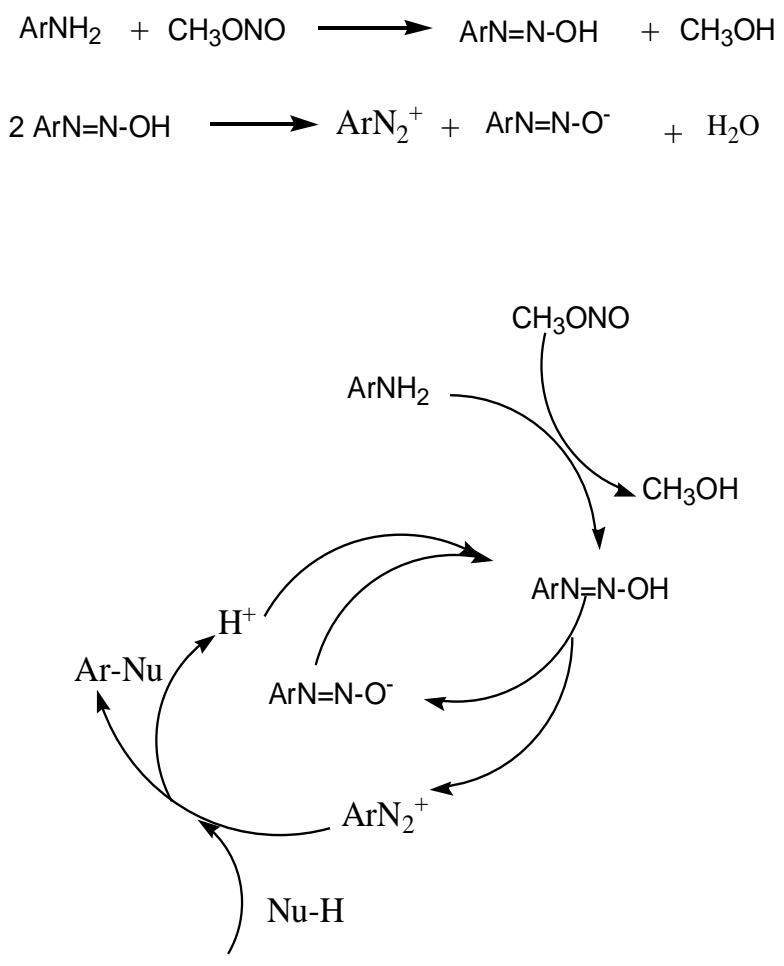

Figure 1. Possible mechanism of the diazotization.

in vacuo to afford $224.7 \mathrm{~g}(94 \%)$ of the product as an organge red solid; mp. $151^{\circ} \mathrm{C}-152^{\circ} \mathrm{C}$, lit. [7] mp. $151^{\circ} \mathrm{C}$ $152^{\circ} \mathrm{C} .1 \mathrm{~b}: \mathrm{IR} v_{\max }\left(\mathrm{cm}^{-1}\right): 823,946,1137,1366,1517,1558,1597 ;{ }^{1} \mathrm{H}$ NMR $\left(\mathrm{CDCl}_{3}\right): \delta 2.39(3 \mathrm{H}, \mathrm{s}), 3.02(6 \mathrm{H}$, s), $6.72(2 \mathrm{H}, \mathrm{d}, J=8.8 \mathrm{~Hz}), 7.25(2 \mathrm{H}, \mathrm{d}, J=7.2 \mathrm{~Hz}), 7.75(2 \mathrm{H}, \mathrm{d}, J=7.6 \mathrm{~Hz}), 7.86(2 \mathrm{H}, \mathrm{d}, J=8.4 \mathrm{~Hz}) ;{ }^{13} \mathrm{C}$ NMR (CDCl $\left.{ }_{3}\right): \delta 21.4,40.3,111.5,122.2,124.7,129.6,139.6,143.7,151.3,152.2 ; \mathrm{MS} \mathrm{m} / \mathrm{z} 120$ (100), $239\left(\mathrm{M}^{+}\right.$, 85); Elemental analysis. Calcd for $\mathrm{C}_{15} \mathrm{H}_{17} \mathrm{~N}_{3}$, C 75.28; H 7.16; N 17.56; Found C 75.15; H 7.28; N 17.47.

Preparation of 4-methyl-2-(p-tolyldiazenyl)phenol (1c): To a mixture of $108.0 \mathrm{~g}$ (1.0 mol) 4-methylphenol, $69.5 \mathrm{~g}(0.50 \mathrm{~mol})$ of potassium carbonate and $400 \mathrm{~mL}$ methanol, the above 4-methylaniline hydrochloride diazonium solution was added dropwise for $5 \mathrm{~h}$ at $0^{\circ} \mathrm{C}$. Then the mixture was poured into $800 \mathrm{~mL}$ water and the precipitated crystals were collected and dried in vacuo to afford $205.8 \mathrm{~g}(91 \%)$ of the product as an organge red solid; mp. $112^{\circ} \mathrm{C}-113^{\circ} \mathrm{C}$, lit. [9] mp. $113^{\circ} \mathrm{C}$. An analytical sample for EA was prepared by recrystallization from ethanol. 1c: IR $v_{\max }\left(\mathrm{cm}^{-1}\right)$ : 808, 829, 1268, 1428, 1491, 1597, 1621; ${ }^{1} \mathrm{H}$ NMR $\left(\mathrm{CDCl}_{3}\right): \delta 2.37(3 \mathrm{H}, \mathrm{s})$, $2.42(3 \mathrm{H}, \mathrm{s}), 6.91(1 \mathrm{H}, \mathrm{d}, J=8.4 \mathrm{~Hz}), 7.13(1 \mathrm{H}, \mathrm{d}, J=8.4 \mathrm{~Hz}), 7.29(2 \mathrm{H}, \mathrm{d}, J=8.0 \mathrm{~Hz}), 7.71(1 \mathrm{H}, \mathrm{s}), 7.75(2$ H, d, $J=8.0 \mathrm{~Hz}$ ), $12.73(1 \mathrm{H}, \mathrm{b})$; 13C NMR (CDCl3): $\delta 20.3,21.5,117.8,122.1,129.0,130.0,132.7,133.8$, 136.9, 141.6, 148.6, 150.5; MS m/z 91 (100), 135 (25), 226 (M+ $\mathrm{M}^{+}$, 90); Elemental analysis. Calcd for $\mathrm{C}_{14} \mathrm{H}_{14} \mathrm{~N}_{2} \mathrm{O}$, C 74.31; H 6.24; N, 12.38; Found C 74.22; H 6.31; N 12.29.

Preparation of 4-hydroxy-3-(p-tolyldiazenyl)acetophenone (1d): To a mixture of $136.0 \mathrm{~g}$ (1.0 mol) 4-hydroxyacetophenone, $69.5 \mathrm{~g}(0.50 \mathrm{~mol})$ of potassium carbonate and $400 \mathrm{~mL}$ methanol, the above 4-methylaniline hydrochloride diazonium solution was added dropwise for $5 \mathrm{~h}$ at $10^{\circ} \mathrm{C}$. Then the mixture was poured into 800 $\mathrm{mL}$ water and the precipitated crystals were collected, recrystallized from $70 \mathrm{~mL}$ of ethanol and dried in vacuo to afford $213.5 \mathrm{~g}(84 \%)$ of the product as a red solid; $\mathrm{mp} .95^{\circ} \mathrm{C}-96^{\circ} \mathrm{C}$. 1d: $\mathrm{IR} v_{\max }\left(\mathrm{cm}^{-1}\right)$ : 704, 817, 1168, 1274, 1356, 1439, 1490, 1597, 1664; ${ }^{1} \mathrm{H}$ NMR $\left(\mathrm{CDCl}_{3}\right): \delta 2.45$ (3 H, s), $2.64(3 \mathrm{H}, \mathrm{s}), 7.07$ (1 H, d, $\left.J=8.8 \mathrm{~Hz}\right), 7.34$ $(2 \mathrm{H}, \mathrm{d}, J=8.0 \mathrm{~Hz}), 7.79(2 \mathrm{H}, \mathrm{d}, J=8.0 \mathrm{~Hz}), 7.99(1 \mathrm{H}, \mathrm{d}, J=8.8 \mathrm{~Hz}), 8.55(1 \mathrm{H}, \mathrm{s}), 13.46(1 \mathrm{H}, \mathrm{b}) ;{ }^{13} \mathrm{C}$ NMR $\left(\mathrm{CDCl}_{3}\right): \delta 21.5,26.3,118.6,122.3,129.8,130.1,132.6,134.2,136.0,142.7,148.1,157.0,196.0 ; \mathrm{MS} \mathrm{m} / \mathrm{z} 91$ (100), 119 (23),135 (20), $254\left(\mathrm{M}^{+}\right.$, 55); Elemental analysis. Calcd for $\mathrm{C}_{15} \mathrm{H}_{14} \mathrm{~N}_{2} \mathrm{O}_{2}$, C 70.85; H 5.55; N 11.02; Found 70.56; H 5.43; N 10.93.

Preparation of 1-(p-tolyldiazenyl)-2-naphthol (1e): To a mixture of $144.0 \mathrm{~g}(1.0 \mathrm{~mol})$ 2-naphthol, $69.5 \mathrm{~g}$ $(0.50 \mathrm{~mol})$ of potassium carbonate and $400 \mathrm{~mL}$ methanol, the above 4-methylaniline hydrochloride diazonium solution was added dropwise for $5 \mathrm{~h}$ at $0^{\circ} \mathrm{C}$. Then the mixture was poured into $800 \mathrm{~mL}$ water and the precipi- 
tated crystals were collected and dried in vacuo to afford $251.5 \mathrm{~g}(96 \%)$ of the product as an orange red solid; mp. $130^{\circ} \mathrm{C}-132^{\circ} \mathrm{C}$, lit. [10] mp. $130^{\circ} \mathrm{C}-132^{\circ} \mathrm{C}$. An analytical sample for EA was prepared by recrystallization from methanol. 1e: IR $v_{\max }\left(\mathrm{cm}^{-1}\right)$ : 750, 813, 986, 1144, 1171, 1207, 1268, 1501, 1552, 1616; 1H NMR $\left(\mathrm{CDCl}_{3}\right)$ : $\delta 2.41(3 \mathrm{H}, \mathrm{s}), 6.92(1 \mathrm{H}, \mathrm{d}, J=8.8 \mathrm{~Hz}), 7.28(2 \mathrm{H}, \mathrm{d}, J=8.0 \mathrm{~Hz}), 7.38(1 \mathrm{H}, \mathrm{t}, J=7.6 \mathrm{~Hz}), 7.55(1 \mathrm{H}, \mathrm{t}, J=$ $7.6 \mathrm{~Hz}), 7.62(1 \mathrm{H}, \mathrm{d}, J=8.0 \mathrm{~Hz}), 7.67(2 \mathrm{H}, \mathrm{d}, J=8.4 \mathrm{~Hz}), 7.72(1 \mathrm{H}, \mathrm{d}, J=9.2 \mathrm{~Hz}), 8.60(1 \mathrm{H}, \mathrm{d}, J=7.6 \mathrm{~Hz})$, $16.17(1 \mathrm{H}, \mathrm{b}) ; 13 \mathrm{C}$ NMR $\left(\mathrm{CDCl}_{3}\right): \delta 21.2,119.1,121.6,123.9,125.3,128.0,128.4,128.5,129.6,130.1,133.5$, 138.3, 138.8, 143.5, 168.4; MS m/z 91 (50), 115 (53), 143 (85), 262( $\left.\mathrm{M}^{+}, 100\right)$; Elemental analysis. Calcd for $\mathrm{C}_{17} \mathrm{H}_{14} \mathrm{~N}_{2} \mathrm{O}$, C 77.84; H 5.38; N 10.68; Found 77.56; H 5.49; N 10.82.

\section{Preparation of Aniline diazonium salt (B)}

$\mathrm{HCl}$ was added dropwise to a mixture of Aniline and methanol in a $100 \mathrm{~mL}$ round-bottomed flask, fitted with a mechanical stirrer, and a gas tube in a well-ventilated hood until $\mathrm{pH}=2$. Methyl nitrite was added through the tube under an icebath for about $2 \mathrm{~h}$. When the reaction was complete, the mixture was stored in fridge as standby material.

Preparation of 4-methy-2-(phenylazoyl) phenol (1f) [11]: In a $100 \mathrm{ml}$ round-bottomed flask, fitted with a mechanical stirrer, and a gas tube in a well-ventilated hood, was placed $1.24 \mathrm{~g}(10 \mathrm{mmol})$ of 4-methylphenol and $15 \mathrm{~mL}$ methanol. After the mixture was dissolved under stirring, Material B was added dropwise under an icebath temperature. Some buffer-solution $\left(\mathrm{Na}_{2} \mathrm{CO}_{3}-\mathrm{AcOH}\right)$ was added until the solution $\mathrm{pH}=8$. The mixture was stirred under the same situation for $30 \mathrm{~min}$, before some $\mathrm{HCl}$ was allowed to add for keeping the mixture $\mathrm{pH}=6$. The precipitate (2.26 g, 93\%) of the mixture was collected and dried over vacuum. An analytical sample for EA was prepared by recrystallization from methanol. mp. $106^{\circ} \mathrm{C}-108^{\circ} \mathrm{C}$.

1f: 4-methy-2-(phenylazoyl) phenol ${ }^{1} \mathrm{H}$ NMR (500 MHz, $\mathrm{CDCl}_{3}$ ): $\delta 12.73$ (s, $\left.1 \mathrm{H}\right), 7.89$ (m, $\left.2 \mathrm{H}\right), 7.78$ (d, $J=$ $1.6 \mathrm{~Hz}, 1 \mathrm{H}), 7.58-7.53$ (m, $2 \mathrm{H}), 7.50$ (m, $J=7.3,3.5,1.2 \mathrm{~Hz}, 1 \mathrm{H}), 7.20$ (m, $J=8.4,2.0 \mathrm{~Hz}, 1 \mathrm{H}), 6.97$ (d, $J$ $=8.4 \mathrm{~Hz}, 1 \mathrm{H}), 2.42(\mathrm{~s}, 3 \mathrm{H}) .{ }^{13} \mathrm{C} \mathrm{NMR}\left(126 \mathrm{MHz}, \mathrm{CDCl}_{3}\right): \delta 150.68,150.54,137.08,134.29,133.01,131.03$, 129.35, 129.21, 122.20, 117.88, 20.31.

Preparation of 1-(phenylazoyl) naphthyl-2-ol (1g): In a $100 \mathrm{ml}$ round-bottomed flask, fitted with a mechanical stirrer, and a gas tube in a well-ventilated hood, was placed $1.60 \mathrm{~g}(10 \mathrm{mmol})$ of naphthyl-2-ol and 10 $\mathrm{mL}$ methanol. After the mixture was dissolved under stirring, Material $\mathrm{B}$ was added dropwise under an icebath temperature. Some buffer-solution $\left(\mathrm{Na}_{2} \mathrm{CO}_{3}-\mathrm{HOAc}\right)$ was added until the solution $\mathrm{pH}=8$. The mixture was stirred under the same situation for $40 \mathrm{~min}$, then some $\mathrm{HCl}$ was added to keep the mixture $\mathrm{pH}=6$. The precipitate (2.5 g, 91\%) of the mixture was collected and dried over vacuum. An analytical sample for EA was prepared by recrystallization from methanol. mp. $131^{\circ} \mathrm{C}-133^{\circ} \mathrm{C}$.

1g: ${ }^{1} \mathrm{H}$ NMR (500 MHz, CDCl $)$ ): $\delta 8.59$ (d, $\left.J=8.2 \mathrm{~Hz}, 1 \mathrm{H}\right), 7.76(\mathrm{~m}, 3 \mathrm{H}), 7.63(\mathrm{~d}, J=7.8 \mathrm{~Hz}, 1 \mathrm{H}), 7.58(\mathrm{~m}$, $J=11.3,4.1 \mathrm{~Hz}, 1 \mathrm{H}), 7.51(\mathrm{t}, J=7.9 \mathrm{~Hz}, 2 \mathrm{H}), 7.42(\mathrm{~m}, 1 \mathrm{H}), 7.33(\mathrm{t}, J=7.4 \mathrm{~Hz}, 1 \mathrm{H}), 7.29$ (s, $1 \mathrm{H}), 6.90(\mathrm{~d}, J$ $=9.4 \mathrm{~Hz}, 1 \mathrm{H}) ;{ }^{13} \mathrm{C}$ NMR $\left(126 \mathrm{MHz}, \mathrm{CDCl}_{3}\right): \delta 171.83,144.81,140.05,133.61,130.08,12$ 9.59, 128.86, 128.62, 128.07, 127.43, 125.72, 124.81, 121.73, 118.61.

Preparation of 4-nitroaniline diazonium salt (C)

$\mathrm{HCl}$ was added dropwise to a mixture of 4-nitroaniline and methanol in a $100 \mathrm{~mL}$ round-bottomed flask, fitted with a mechanical stirrer, and a gas tube in a well-ventilated hood until $\mathrm{pH}=2$. Methyl nitrite was added through the tube under an icebath for about $2 \mathrm{~h}$. When the reaction was complete, the mixture was stored in fridge as standby material.

Preparation of 4-(4-nitrophenylazoyl)-phenol (1h): In a $100 \mathrm{ml}$ round-bottomed flask, fitted with a mechanical stirrer, and a gas tube in a well-ventilated hood, was placed $0.98 \mathrm{~g}(10 \mathrm{mmol})$ of phenol and $10 \mathrm{~mL}$ methanol. After the mixture was dissolved under stirring, Material $\mathrm{C}$ was added dropwise under an icebath temperature. Some buffer-solution $\left(\mathrm{Na}_{2} \mathrm{CO}_{3}\right.$-HOAc) was added until the solution $\mathrm{pH}=8$. The mixture was stirred under the same situation for $2 \mathrm{~h}$, then some $\mathrm{HCl}$ was added to keep the mixture $\mathrm{pH}=6$. The precipitate $(2.15 \mathrm{~g}$, $85 \%$ ) of the mixture was collected and dried over vacuum. An analytical sample for EA was prepared by recrystallization from methanol. mp. $119^{\circ} \mathrm{C}-120^{\circ} \mathrm{C}$.

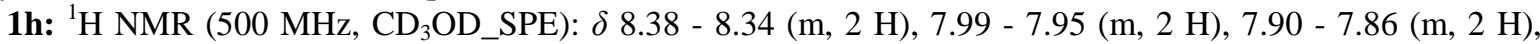
6.97 - 6.92 (m, $2 \mathrm{H})$; ${ }^{13} \mathrm{CNMR}$ (126 MHz, CD $\left.{ }_{3} \mathrm{OD} \_\mathrm{SPE}\right): \delta 162.17,156.12,148.15,146.16,125.47,124.31$, 122.63, 115.59 .

Preparation of 2-methyl-6-ethyl-4-(4-nitrophenylazoyl)aniline (1i): In a $100 \mathrm{ml}$ round-bottomed flask, fitted with a mechanical stirrer, and a gas tube in a well-ventilated hood, was placed $2 \mathrm{~g}$ (10 mmol) of phenol and $10 \mathrm{~mL}$ methanol. After the mixture was dissolved under stirring, $\mathrm{HCl}$ was added to keep the mixture $\mathrm{pH}=2$. 
Material C was added dropwise under an icebath temperature. The mixture was stirred under the same situation for $3 \mathrm{~h}$. The precipitate (3.4 g, 83\%) of the mixture was collected and dried over vacuum.

1i: ${ }^{1} \mathrm{H}$ NMR (500 MHz, $\left.\mathrm{CDCl}_{3}\right): \delta 13.13$ - 13.06 (m, $\left.2 \mathrm{H}\right), 12.69$ - $12.62(\mathrm{~m}, 2 \mathrm{H}), 12.33(\mathrm{~s}, 2 \mathrm{H}), 7.33$ (q, $J=$ $7.4 \mathrm{~Hz}, 2 \mathrm{H}), 6.95$ (s, $3 \mathrm{H}), 5.96(\mathrm{t}, J=7.4 \mathrm{~Hz}, 3 \mathrm{H})$. Elemental analysis. Calcd for $\mathrm{C}_{16} \mathrm{H}_{16} \mathrm{~N}_{4} \mathrm{O}_{2}$, C 63.28; H 5.47; N 19.58; Found 63.38; H 5.63; N 19.72.

Preparation of 1-(4-nitrophenylazoyl)naphthyl-2-ol (1j): In a $100 \mathrm{ml}$ round-bottomed flask, fitted with a mechanical stirrer, and a gas tube in a well-ventilated hood, was placed $1.60 \mathrm{~g}$ (10 mmol) of phenol and $10 \mathrm{~mL}$ methanol. After the mixture was dissolved under stirring, Material $\mathrm{C}$ was added dropwise under an icebath temperature. Some buffer-solution $\left(\mathrm{Na}_{2} \mathrm{CO}_{3}-\mathrm{HOAc}\right)$ was added until the solution $\mathrm{pH}=8$. The mixture was stirred under the same situation for $40 \mathrm{~min}$, then some $\mathrm{HCl}$ was added to keep the mixture $\mathrm{pH}=6$. The precipitate $(2.76$ g, 85\%) of the mixture was collected and dried over vacuum. An analytical sample for EA was prepared by recrystallization from methanol. mp. $251^{\circ} \mathrm{C}-254^{\circ} \mathrm{C}$.

1j: ${ }^{1} \mathrm{H}$ NMR (500 MHz, $\mathrm{CDCl}_{3}$ ): $\delta 16.14$ (s, $\left.1 \mathrm{H}\right), 8.45$ (d, $\left.J=8.0 \mathrm{~Hz}, 1 \mathrm{H}\right), 8.35$ (d, $\left.J=8.9 \mathrm{~Hz}, 2 \mathrm{H}\right), 7.72$ (t, $J=7.8 \mathrm{~Hz}, 3 \mathrm{H}$ ), 7.58 (dd, $J=17.0,7.7 \mathrm{~Hz}, 2 \mathrm{H}), 7.46$ (t, $J=7.2 \mathrm{~Hz}, 1 \mathrm{H}), 6.73$ (d, $J=9.0 \mathrm{~Hz}, 1 \mathrm{H})$.

Preparation of disperse Yellow RGFL (1k): In a $100 \mathrm{ml}$ round-bottomed flask, fitted with a mechanical stirrer, and a gas tube in well-ventilated hood, was placed $1.97 \mathrm{~g}(10 \mathrm{mmol})$ of p-Aminoazobenzene and $15 \mathrm{~mL}$ methanol. After the mixture was dissolved under stirring, $\mathrm{HCl}$ was added to keep the mixture $\mathrm{pH}=2$. Methyl nitrite was added through the tube under an icebath for about $3 \mathrm{~h}$. When the reaction was complete, the mixture was stored in fridge as standby material (D).

In another $100 \mathrm{ml}$ round-bottomed flask, fitted with a mechanical stirrer, and a gas tube in a well-ventilated hood, was placed $1.0 \mathrm{~g}(10 \mathrm{mmol})$ of phenol and $10 \mathrm{~mL}$ methanol. After the mixture was dissolved under stirring, Material D was added dropwise under an icebath temperature. Some buffer-solution $\left(\mathrm{Na}_{2} \mathrm{CO}_{3}-\mathrm{HOAc}\right)$ was added until the solution $\mathrm{pH}=8$. The mixture was stirred under the same situation for $1.5 \mathrm{~h}$, the precipitate (2.9 g, $90 \%$ ) of the mixture was collected and dried over vacuum. An analytical sample for EA was prepared by recrystallization from methanol. mp. $222^{\circ} \mathrm{C}-225^{\circ} \mathrm{C}$.

1k: ${ }^{1} \mathrm{H}$ NMR (400 MHz, DMSO): $\delta 10.47$ (s, $1 \mathrm{H}$ ), 8.08 - 8.02 (m, $2 \mathrm{H}$ ), 8.00 (d, J = 8.6 Hz, $2 \mathrm{H}$ ), 7.93 (d, $J$ = 6.2 Hz, $2 \mathrm{H}), 7.86$ (d, $J=8.6 \mathrm{~Hz}, 2 \mathrm{H}), 7.60$ (d, $J=6.7 \mathrm{~Hz}, 3 \mathrm{H}), 6.98$ (d, $J=8.7 \mathrm{~Hz}, 2 \mathrm{H})$.

Preparation of 4-aminobenzenesulfonic acid diazonium salt (E): In a $100 \mathrm{ml}$ round-bottomed flask, fitted with a mechanical stirrer, and a gas tube in a well-ventilated hood, was placed $2.1 \mathrm{~g}$ (10 mmol) of 4-Aminobenzenesulfonic Acid and $15 \mathrm{~mL}$ 5\% NaOH. After the mixture was dissolved under stirring. Methyl nitrite was added through the tube under an icebath for about $5 \mathrm{~h}$. When the reaction was complete, the mixture was stored in fridge as standby material (E).

Preparation of 4-(N,N-dimethyl benzene amino azo)-benzene sulfonic acid (2a): In another $100 \mathrm{ml}$ roundbottomed flask, fitted with a mechanical stirrer, and a gas tube in a well-ventilated hood, was placed $1.2 \mathrm{~g}$ (10 mmol) of N,N-dimethylaniline and $10 \mathrm{~mL}$ glacial acetic acid. After the mixture was dissolved under stirring, Material E was added dropwise under an icebath temperature. The mixture was stirred under the same situation for $1.5 \mathrm{~h}$, the precipitate (2.49 g, 83\%) of the mixture was collected and dried over vacuum. An analytical sample for EA was prepared by recrystallization from methanol.

2a: ${ }^{1} \mathrm{H}$ NMR (400 MHz, DMSO): $\delta 7.80$ (d, $\left.J=8.9 \mathrm{~Hz}, 2 \mathrm{H}\right), 7.77$ - 7.69 (m, $\left.4 \mathrm{H}\right), 6.83$ (d, $\left.J=9.0 \mathrm{~Hz}, 2 \mathrm{H}\right)$, 3.06 (s, $6 \mathrm{H}) ;{ }^{13} \mathrm{C}$ NMR (101 MHz, DMSO): $\delta$ 152.96, 152.58, 149.16, 142.93, 126.93, 125.20, 121.59, 111.92, 40.21. Elemental analysis. Calcd for $\mathrm{C}_{14} \mathrm{H}_{15} \mathrm{~N}_{3} \mathrm{SO}_{3}$, C 55.08; H 4.92; N 13.77; Found C 54.88; H 4.86; N 13.66.

Preparation of 4-(2,4-dihydroxy phenyl azo)-benzene sulfonic acid (2b): In another 100 ml round-bottomed flask, fitted with a mechanical stirrer, and a gas tube in a well-ventilated hood, was placed $1.5 \mathrm{~g}$ (10 mmol) of m-dihydroxybenzene and $10 \mathrm{~mL}$ methanol. After the mixture was dissolved under stirring, Material D was added dropwise under an icebath temperature. Some buffer-solution (NaOH-HOAc) was added until the solution $\mathrm{pH}=8$. The mixture was stirred under the same situation for $2 \mathrm{~h}$, then some $\mathrm{HCl}$ was added to keep the mixture $\mathrm{pH}=6$. the precipitate (3.3 g, 82\%) of the mixture was collected and dried over vacuum. An analytical sample for EA was prepared by recrystallization from methanol [12].

2b: ${ }^{1} \mathrm{H}$ NMR (400 MHz, DMSO): $\delta 12.40$ (s, $\left.1 \mathrm{H}\right), 10.80(\mathrm{~s}, 1 \mathrm{H}), 7.80$ (d, $\left.J=8.4 \mathrm{~Hz}, 2 \mathrm{H}\right), 7.74$ (d, $J=8.5$ $\mathrm{Hz}, 2 \mathrm{H}), 7.66(\mathrm{~m}, J=8.6,4.1 \mathrm{~Hz}, 2 \mathrm{H}), 6.52(\mathrm{~m}, J=8.8,2.4 \mathrm{~Hz}, 1 \mathrm{H}), 6.41(\mathrm{~d}, J=2.2 \mathrm{~Hz}, 1 \mathrm{H}) ;{ }^{13} \mathrm{C} \mathrm{NMR}$ (101 MHz, DMSO): $\delta$ 163.70, 156.97, 150.92, 149.26, 132.72, 130.15, 127.11, 121.52, 109.69, 103.38. Elemental analysis. Calcd for $\mathrm{C}_{12} \mathrm{H}_{10} \mathrm{~N}_{2} \mathrm{SO}_{5}$, C49.98; H 3.40; N 9.52; Found C 49.84; H 3.26; N 9.48.

Preparation of 4-(2-hydroxyl naphthyl azo)-benzene sulfonic acid (2c): 
In another $100 \mathrm{ml}$ round-bottomed flask, fitted with a mechanical stirrer, and a gas tube in a well-ventilated hood, was placed $1.8 \mathrm{~g} \mathrm{(10} \mathrm{mmol)} \mathrm{of} \mathrm{naphthyl-2-ol} \mathrm{and} 15 \mathrm{~mL}$ methanol. After the mixture was dissolved under stirring, Material D was added dropwise under an icebath temperature. Some buffer-solution (NaOH-HOAc) was added until the solution $\mathrm{pH}=8$. The mixture was stirred under the same situation for $2 \mathrm{~h}$, then some $\mathrm{HCl}$ was added to keep the mixture $\mathrm{pH}=6$. The precipitate ( $3.6 \mathrm{~g}$, 88\%) of the mixture was collected and dried over vacuum. An analytical sample for EA was prepared by recrystallization from methanol.

2c: ${ }^{1} \mathrm{H}$ NMR (400 MHz, DMSO): $\delta 15.84(\mathrm{~s}, 1 \mathrm{H}), 8.53$ (d, $\left.J=8.1 \mathrm{~Hz}, 1 \mathrm{H}\right), 7.95$ (d, $\left.J=9.4 \mathrm{~Hz}, 1 \mathrm{H}\right), 7.84$ 7.79 (m, $2 \mathrm{H}$ ), 7.76 (d, $J=7.7 \mathrm{~Hz}, 3 \mathrm{H}), 7.61$ (t, $J=7.6 \mathrm{~Hz}, 1 \mathrm{H}), 7.46$ (t, $J=7.4 \mathrm{~Hz}, 1 \mathrm{H}$ ), 6.89 (dd, $J=9.4,4.7$ $\mathrm{Hz}, 1 \mathrm{H}), 1.05$ (t, $J=7.0 \mathrm{~Hz}, 1 \mathrm{H}) .{ }^{13} \mathrm{C}$ NMR $(101 \mathrm{MHz}, \mathrm{DMSO}): \delta 170.63$ (d, $\left.J=8.3 \mathrm{~Hz}\right), 147.52(\mathrm{~d}, J=8.5$ Hz), 144.93 (d, $J=9.2 \mathrm{~Hz}$ ), 140.79, 133.05, 129.76, 129.55, 129.31, 128.21, 127.55, 126.39, 124.60 (d, $J=6.8$ $\mathrm{Hz}), 121.81$ (d, $J=7.0 \mathrm{~Hz}), 118.35$ (d, $J=11.8 \mathrm{~Hz}$ ). Elemental analysis. Calcd for $\mathrm{C}_{16} \mathrm{H}_{12} \mathrm{~N}_{2} \mathrm{SO}_{4}, \mathrm{C} 58.54 ; \mathrm{H}$ 3.64; N8.54; Found C 58.48; H 3.56; N 8.47.

Preparation of 4-(2-hydroxy-5-methyl phenyl azo)-benzene sulfonic acid (2d): In another $100 \mathrm{ml}$ roundbottomed flask, fitted with a mechanical stirrer, and a gas tube in a well-ventilated hood, was placed $1.1 \mathrm{~g}$ (10 mmol) of 4-methylphenol and $15 \mathrm{~mL}$ methanol. After the mixture was dissolved under stirring, Material D was added dropwise under an icebath temperature. Some buffer-solution (NaOH-HOAc) was added until the solution $\mathrm{pH}=8$. The mixture was stirred under the same situation for $2 \mathrm{~h}$, then some $\mathrm{HCl}$ was added to keep the mixture $\mathrm{pH}=6$. The precipitate (2.58 g, 87\%) of the mixture was collected and dried over vacuum. An analytical sample for EA was prepared by recrystallization from methanol [13].

2d: ${ }^{1} \mathrm{H}$ NMR (400 MHz, DMSO): $\delta 7.92-7.94$ (d, 2 H), 7.76 - 7.78 (d, 2 H), 7.57 (s, 1 H), 6.64 - 6.68 (d, 2 $\mathrm{H}), 6.62$ - $6.64(\mathrm{~d}, 1 \mathrm{H}), 2.29(\mathrm{t}, 3 \mathrm{H})$ Elemental analysis. Calcd for $\mathrm{C}_{13} \mathrm{H}_{12} \mathrm{~N}_{2} \mathrm{SO}_{4}$, C53.42; H 4.10; N9.59; Found C 53.28; H 3.97; N 9.47.

Preparation of 4-(4-amino-2,6-dimethyl phenyl azo)-benzene sulfonic acid (2e): In another $100 \mathrm{ml}$ roundbottomed flask, fitted with a mechanical stirrer, and a gas tube in a well-ventilated hood, was placed $1.1 \mathrm{~g} \mathrm{(10}$ mmol) of 2,6-dimethylaniline and $15 \mathrm{~mL}$ methanol. After the mixture was dissolved under stirring, Material $\mathrm{E}$ was added dropwise under an icebath temperature. Some buffer-solution (NaOH-HOAc) was added until the solution $\mathrm{pH}=8$. The mixture was stirred under the same situation for $2 \mathrm{~h}$, then some $\mathrm{HCl}$ was added to keep the mixture $\mathrm{pH}=6$. The precipitate $(2.4 \mathrm{~g}, 81 \%)$ of the mixture was collected and dried over vacuum. An analytical sample for EA was prepared by recrystallization from methanol [14].

2e: ${ }^{1} \mathrm{H}$ NMR (400 MHz, $\mathrm{CDCl}_{3}$ ): $\delta 7.67$ - 7.67 (d, $2 \mathrm{H}$ ), 7.41 - 7.44 (m, $4 \mathrm{H}$ ), 6.47 - 6.49 (d, $\left.2 \mathrm{H}\right), 2.71$ (s, 6 H). Elemental analysis. Calcd for $\mathrm{C}_{14} \mathrm{H}_{15} \mathrm{~N}_{3} \mathrm{SO}_{3}$, C55.08; H4.92; N13.77; Found C 55.18; H 5.06; N 13.8.

\section{Conclusion}

In conclusion, we have developed a clean preparation of aryl diazonium ions using methyl nitrite. The processes were easy operations, environmentally benign conditions and high yields of the products. We believe that such a simple and safe methodolody would initiate a growing interest for the chemistry of diazonium salt and introduce its further practical use as azo dyes and pigments.

\section{Acknowledgements}

We thank the Natural Science Foundation of Zhejiang Province (Y4100077), the Project of Zhejiang Key Scientific and Technological Innovation Team (2010R50017), the Science and Technology Foundations of Hangzhou (20112833N03 and 20122511A43) and the Program for Changjiang Scholars and Innovative Research Team in Chinese University (IRT 1231).

\section{References}

[1] Griess, J.P. (1858) Vorläufige Notiz über die Einwirkung von salpetriger Säure auf Amidinitro- und Aminitrophenylsäure. Justus Liebigs Annalen der Chemie, 1858, 123-125. http://dx.doi.org/10.1002/jlac.18581060114

[2] Amin, Z., Abdol, R., Hajipour, L.K., Bibi, F., Mirjalili and Alireza, N.C. (2009) Rapid and Efficient Diazotization and Diazo Coupling Reactions on Silica Sulfuric. Dyes and Pigments, 81, 240-244.

[3] Doyle, M.P, Siegfried, B. and Dellaria Jr., J.F. (1977) Alkyl Nitrite-Metal Halide Deamination Reactions. 2. Substitutive Deamination of Arylamines by Alkyl Nitrites and Copper(II) Halides. A Direct and Remarkably Efficient Conversion of Arylamines to Aryl Halides. The Journal of Organic Chemistry, 42, 2426-2429. 
http://dx.doi.org/10.1021/jo00434a017

[4] Filimonov, V.D., Semenischeva, N.I., Krasnokutskaya, E.A., Trelyakov, A.N., Hwang, H.Y. and Chi, K.W. (2008) Sulfonic Acid Based Cation-Exchange Resin: A Novel Proton Source for One-Pot Diazotization-Iodination of Aromatic Amines in Water. Synthesis, 2, 185-190. http://dx.doi.org/10.1055/s-2007-990950

[5] Filimonov, V.D., Trusova, M., Postnikov, P., Krasnokutskaya, E.A., Lee, Y.M., Hwang, H.Y., Kim, H. and Chi, K.W. (2008) Unusually Stable, Versatile, and Pure Arenediazonium Tosylates: Their Preparation, Structures, and Synthetic Applicability. Organic Letters, 10, 3961-3964. http://dx.doi.org/10.1021/ol8013528

[6] Dabbagh, H.A., Teimouri, A. and Chermahini, A.N. (2007) Green and Efficient Diazotization and Diazo Coupling Reactions on Clays. Dyes Pigments, 73, 239-244. http://dx.doi.org/10.1016/j.dyepig.2005.12.002

[7] Chen, N., Barra, M., Lee, I. and Chahal, N. (2002) Substituent Effects on the Thermal Cis-to-Trans Isomerization of 1,3-Diphenyltriazenes in Aqueous Solution. The Journal of Organic Chemistry, 67, 2271-2277. http://dx.doi.org/10.1021/jo011094d

[8] Gu, H., Yu, B., Zhang, P.F. and Xu, W.M. (2009) Organic Preparations and Procedures International: The New Journal for Organic Synthesis. Organic Preparations and Procedures International, 41, 162-164. http://dx.doi.org/10.1080/00304940902802172

[9] Jirandehi, H.F. (2010) Synthesis of Some Aryl Azo-Compounds under Mild Conditions. Asian Journal of Chemistry, 22, 68.

[10] Burkhard, R.K. and Moore, F.A. (1955) Interactions of Homologs of Carcinogenic Azo Dyes and Bovine Serum Albumin $^{1-3}$. Journal of the American Chemical Society, 77, 6057-6059. http://dx.doi.org/10.1021/ja01627a081

[11] Prasanta, K.S., Joydip, C. and Samaresh, B. (1997) Synthesis, Characterization, Redox Properties and Reactivities of a Group of Phenolato Complexes of Ruthenium(III). 81-87.

[12] Esnault, C., Nicolas, D., Guy, L. and Jean-François, P. (2013) One-Pot in Situ Mixed Film Formation by Azo Coupling and Diazonium Salt Electrografting. ChemPhysChem, 24, 1793-1796.

[13] Hodgson, H.H. and Marsden, E. (1943) 98. The Decomposition of Diazo-Compounds in Neutral Solution. Some Observations on the Diazo-Coupling Reaction. Journal of the Chemical Society, 65, 379-384. http://dx.doi.org/10.1039/jr9430000379

[14] Manuel, I.V., Claudio, O.K., Rita, H.D.R. and Laura, I.R. (2011) A Green Alternative to Synthetize Azo Compounds. Dyes and Pigments, 90, 259-263. 
Scientific Research Publishing (SCIRP) is one of the largest Open Access journal publishers. It is currently publishing more than 200 open access, online, peer-reviewed journals covering a wide range of academic disciplines. SCIRP serves the worldwide academic communities and contributes to the progress and application of science with its publication.

Other selected journals from SCIRP are listed as below. Submit your manuscript to us via either submit@scirp.org or Online Submission Portal.
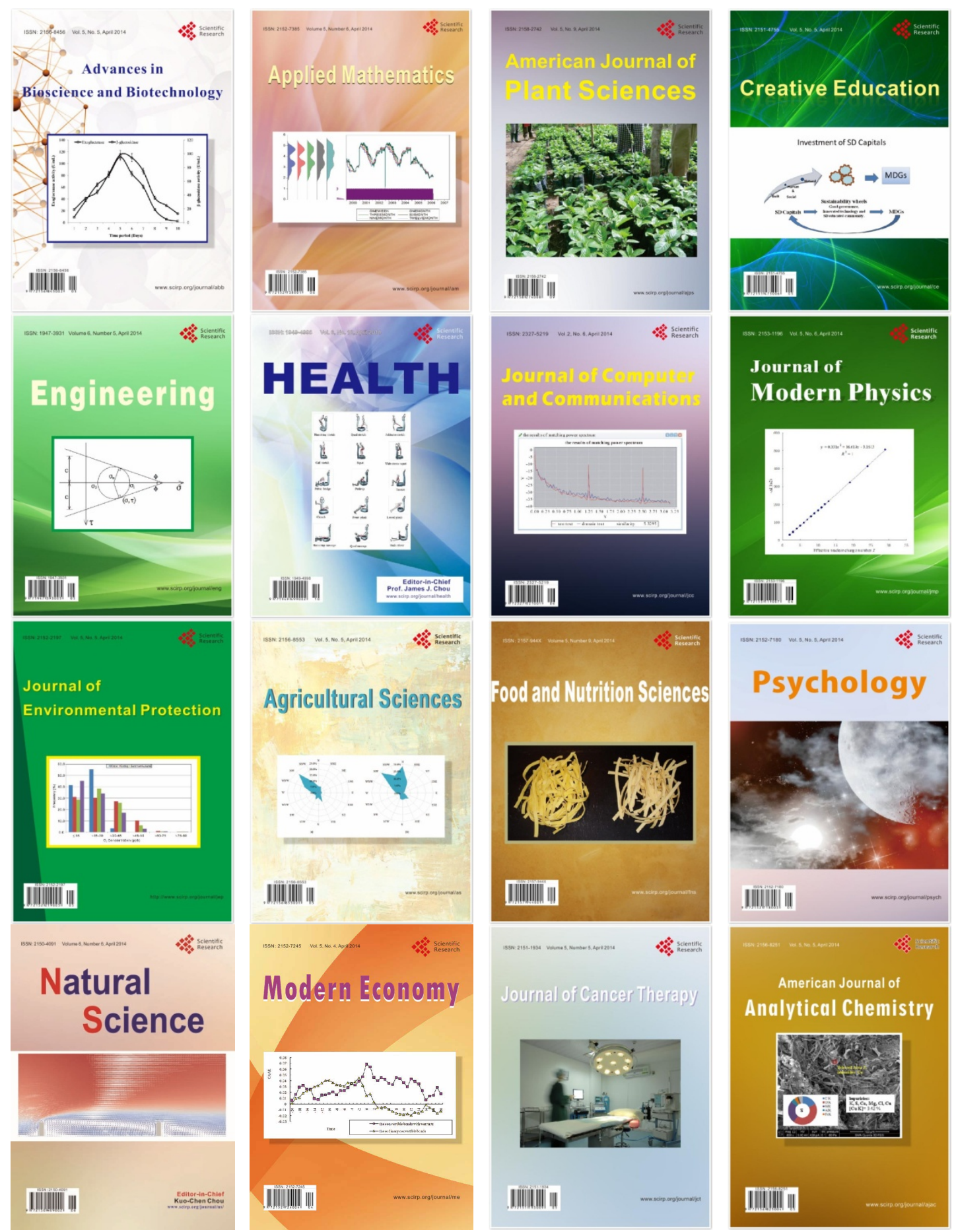